\title{
Pendampingan Redesign Pembelajaran Masa Pandemi Covid- 19 bagi Tenaga Pendidik di Lembaga Pendidikan berbasis Pesantren di Jawa Timur
}

\author{
Muh Barid Nizarudin Wajdi \\ Program Doktoral \\ Universitas Muhammadiyah Malang \\ E-mail: baridnizar84@gmail.com \\ Sri Mulyani, Khoirul Anwar, \\ Lailatul Istiqomah, Fauziyah \\ Rahmawati, Sholihatul Atik \\ Hikmawati, Diah Retno Ningsih \\ IAI Sunan Kalijogo Malang \\ E-mail: srimulyanife05@gmail.com
}

\author{
M. Burhanuddin Ubaidillah
STAI Darussalam Krempyang Nganjuk
E-mail: burhanudinubaidillah@gmail.com \\ M. Burhanuddin Ubaidillah
STAI Darussalam Krempyang Nganjuk
E-mail: burhanudinubaidillah@gmail.com \\ M. Burhanuddin Ubaidillah
STAI Darussalam Krempyang Nganjuk
E-mail: burhanudinubaidillah@gmail.com
}

Hasan Syaiful Rizal

Universitas Yudharta Pasuruan

E-mail: hsr@yudharta.ac.id

\author{
Article History: \\ Received: 2020-03-14 \\ Revised: 2020-04-15 \\ Accepted: 2020-05-31
}

\begin{abstract}
Education has been one of the most affected sectors since the corona pandemic. Like many countries affected, the Indonesian government has taken several precautions needed to reduce the spread of the virus. This causes obstacles in all educational activities, especially in the teaching and learning process. This article aims to illustrate assistance in redesigning learning model in this pandemic period by applying an online service-learning approach. The results show that educators are given many choices of online media that can be used for the teaching and learning processes, ranging from social media (WhatsApp and Facebook), learning management systems media (google classroom, Edmodo), and video conferencing (Zoom, google meet). In redesigning this learning model, educators mostly used WhatsApp as the main media in delivering the material in online classes, while the Google Classroom LMS media was used for managing the students' assignments.
\end{abstract}

Keywords: Covid-19

Pandemic, Learning Redesign,

Learning Management

System, Service-Learning

Approach

\section{Pendahuluan}

Sejak munculnya penyakit pernapasan akut yang disebabkan oleh Coronavirus SARS-COV-2 yang berasal dari Wuhan, provinsi Hubei di Cina pada bulan Desember 20191 yang lebih dikenal dengan Covid-19 dan deklarasi berikutnya oleh Organisasi Kesehatan Dunia (WHO) sebagai keadaan darurat kesehatan masyarakat dari

\footnotetext{
${ }^{1}$ Dezan Shira, “China Extends Lunar New Year Holiday to Feb 2, Shanghai to Feb 9," last modified 2020, accessed April 5, 2020, https://www.china-briefing.com/news/china-extends-lunar-new-yearholiday-february-2-shanghai-february-9-contain-coronavirus-outbreak/.
} 
keprihatinan internasional yang menimbulkan ancaman bagi koeksistensi sosial, ekonomi global dan keberlanjutan, banyak negara di seluruh dunia telah merespon serius terhadap pandemi ${ }^{2}$. Coronavirus adalah masalah kesehatan yang serius yang membutuhkan kerja sama dan tindakan pencegahan yang harus diambil untuk menghentikan penyebaran virus. Negara di seluruh dunia telah mengambil tindakan seperti menyatakan keadaan darurat, memperbaiki ketentuan medis, meminimalkan pengumpulan massal, batas penutupan, pusat rekreasi, sekolah, Perpustakaan, Bisnis, kegiatan keagamaan dan olahraga, pengawasan kota yang ketat menegakkan pengawasan kota yang ketat, karantina individu dan isolasi berskala besar ${ }^{3}$.

Covid-19 membuat orang Indonesia khawatir karena banyak orang yang terpengaruh oleh transmisi virus. Karena pemerintah mengadopsi kebijakan pembatasan sosial skala besar (PSBB) sebagai langkah untuk mengurangi atau mematahkan rantai distribusi Covid-194. Pemerintah Indonesia melalui Menteri Pendidikan ${ }^{5}$ pada tanggal 12 Maret, 2020 mengumumkan liburnya semua kegiatan Pendidikan di semua Lembaga Pendidikan di negara ini telah ditunda untuk semua kegiatan kelas, acara akademik seperti konferensi, dan seminar6 .

Hal ini dilakukan oleh pemerintah, sebagai bagian dari langkah pencegahan untuk membantu mengekang penyebaran penyakit di negara ini. Hanya saja, pemerintah terkesan belum memiliki rencana cadangan terkait pembelajaran di masa pandemi ini. Sehingga semua kegiatan akademik terganggu sampai dalam waktu yang tidak ditentukan. Hal ini dikarenakan beberapa sebab, diantaranya adalah apakah lembaga pendidikan memiliki teknologi yang dibutuhkan untuk melibatkan siswa dalam pembelajaran jarak jauh? Apakah guru memiliki pengalaman dan sumber untuk mempersiapkan dan memberikan pelajaran online secara langsung? Apakah semua orang tua atau wali memiliki teknologi dan waktu yang diperlukan untuk mendaftarkan lingkungan mereka dalam pelajaran online?

Meskipun, penutupan mendadak Lembaga pendidikan membawa efek yang cukup mengejutkan, di sisi lain, kejadian ini berhasil menyorot kelemahan sistem pendidikan di negeri ini. Sistem pendidikan di Indonesia didasarkan pada pendidikan kelas tradisional yang mengharuskan siswa untuk menghadiri sekolah dan kelas setiap hari. Metodologi pembelajaran dilakukan dengan sistem tatap muka, di mana buku

\footnotetext{
2 WHO, “Coronavirus," last modified 2020, accessed April 5, 2020, https://www.who.int/healthtopics/coronavirus\#tab=tab_1.

3 Peilin Liu et al., "Prevalence and Genetic Diversity Analysis of Human Coronaviruses among Cross-Border Children,” Virology Journal 14, no. 1 (November 22, 2017): 230.

${ }^{4}$ Rindam Nasruddin and Islamul Haq, "Pembatasan Sosial Berskala Besar (PSBB) Dan Masyarakat Berpenghasilan Rendah," SALAM: Jurnal Sosial dan Budaya Syar-i 7, no. 7 (2020).

5 "Kementerian Pendidikan Dan Kebudayaan » Republik Indonesia," accessed June 10, 2020, https://www.kemdikbud.go.id/main/blog/2020/03/sikapi-covid19-kemendikbud-terbitkan-dua-suratedaran.

6 Muh Barid Nizarudin Wajdi et al., "Education Policy Overcome Coronavirus, A Study of Indonesians," EDUTEC: Journal of Education And Technology 3, no. 2 (2020): 96-106.
} 
pelajaran, papan tulis dan atau Whiteboard digunakan oleh guru sebagai bahan instruksional.

Ini tidak cukup memastikan pembelajaran terus menerus selama krisis seperti pandemi ini, ketika siswa wajib dijaga agar tidak ke sekolah demi keselamatan. Hasil dari beberapa penelitian mengenai pelaksanaan pendidikan online, di mana teknologi informasi dan komunikasi yang digunakan untuk membantu dalam proses pembelajaran telah mengungkapkan bahwa sangat sedikit lembaga pendidikan telah menggunakan kemajuan teknologi berbasis online. Dalam skala besar, integrasi teknologi pendidikan di sekolah, masih sangat rendah ${ }^{7}$. Oleh karena itu, tantangan ini mengharuskan perlu untuk mencari opsi lain untuk membantu guru dan siswa yang dalam proses pengajaran dan pendidikan.

Berdasarkan latar belakang tersebut, maka Tim Pendamping melakukan pendampingan terhadap para tenaga pendidik di 4 (empat) lembaga pendidikan berbasis pesantren di Jawa Timur, yaitu lembaga pendidikan di bawah naungan Yayasan Pondok Pesantren Sunan Kalijogo Malang, Yayasan Pondok Pesantren Miftahul Ula Nganjuk, Yayasan Pondok Pesantren Al-Ghozali Nganjuk, dan Yayasa Pondok Pesantren Darut Taqwa Sengonagung Pasuruan dalam redesign pembelajaran pada masa pandemic Covid-19, dari bersifat klasikal menjadi pembelajaran online.

\section{Metode}

Metode yang digunakan dalam program pendampingan ini adalah menggunakan online service learning. ${ }^{8}$ Pendekatan online service learning dalam pendampingan ini dilakukan untuk mendampingi para tenaga pendidik supaya dapat belajar bersama dalam simulasi proses belajar mengajar dengan menggunakan kelas virtual (online), yang dilakukan dalam 3 tahap, yakni tahap persiapan, tahap melayani, dan tahap refleksi. ${ }^{9}$

7 C M Toquero, "Challenges and Opportunities for Higher Education amid the COVID-19 Pandemic: The Philippine Context," Pedagogical Research 5, no. 4 (2020); E. J. Chukwuemeka et al., "Assessing Pre-Service Teachers'technological Pedagogical Content Knowledge Self-Efficacy Towards Technology Integration In Colleges Of Education In South-West Nigeria" (n.d.).

${ }^{8}$ Leora S Waldner, Murray C Widener, and Sue Y McGorry, "E-Service Learning: The Evolution of Service-Learning to Engage a Growing Online Student Population," Journal of Higher Education Outreach and Engagement (2012): 123-150.Sholihatul Atik Hikmawati, "Penerapan Mode Kooperatif Model TeamsGames-Tournaments (TGT) Untuk Meningkatkan Motivasi Dan Hasil Belajar Maharah Qira'ah Siswa Kelas XII Bahasa MAN Batu," Penerapan Mode Kooperatif Model Teams-Games-Tournaments (TGT) Untuk Meningkatkan Motivasi Dan Hasil Belajar Maharah Qira'ah Siswa Kelas XII Bahasa MAN Batu/Sholihatul Atik Hikmawati (Universitas Negeri Malang. Program Studi Pendidikan Bahasa Arab, 2010).

9 Irene Nusanti, "Strategi Service Learning Sebuah Kajian Untuk Mengembangkan Kegiatan Pembelajaran," Jurnal Pendidikan dan Kebudayaan 20, no. 2 (2014): 251-260; Ayi Olim, "Mencari Metode Pendidikan Karakter Untuk Paud : Belajar Berbasis Layanan ( Service Learning )," in Proceedings of The 4th International Conference on Teacher Education; Join Conference UPI \& UPSI (Bandung: UPI \& UPSI Bandung, 2010), 146-161. 
Pada tahap pertama, Tim Pendamping ini melakukan persiapan pendampingan. Persiapan ini dilakukan melalui pemetaan problem awal yang dihadapi di masingmasing lembaga pendidikan di bawah naungan 4 (empat) lembaga pendidikan berbasis pesantren, diskusi dengan pemangku kebijakan pihak yayasan, dan persiapan untuk melaksanakan pendampingan bagi para tenaga pendidik di bawah naungan yayasan dari 4 (empat) lembaga pendidikan tersebut.

Tahap kedua, layanan. Dalam tahap ini, tim melakukan pendampingan untuk bersama-sama dengan para pendidik melakukan simulasi pembelajaran virtual dengan menggunakan beragam media online sebagai media belajar. Dalam tahap ini, para pendidik dikenalkan ragam varian media online yang bisa digunakan dalam proses belajar mengajar dengan para siswanya. Baik media berbasis social media, learning management system (LMS), maupun pemanfaatan video conference.

Tahap ketiga, refleksi. Dalam tahap ini tim melakukan evaluasi dari proses pendampingan yang sudah dilakukan kepada para pendidikan di bawah naungan empat yayasan pendidikan pondok pesantren tersebut. Adapun waktu pendampingan dilakukan pada bulan Maret-April 2020.

\section{Hasil dan Diskusi}

Terjadinya pandemi Covid-19 'memaksa' lembaga pendidikan untuk melakukan redesign proses pembelajaran, dari klasikal menjadi belajar di rumah. Hal ini juga dirasakan oleh lembaga-lembaga pendidikan di 4 (empat) lembaga pendidikan berbasis pesantren di Jawa Timur, yaitu lembaga pendidikan di bawah naungan Yayasan Pondok Pesantren Sunan Kalijogo Malang, Yayasan Pondok Pesantren Miftahul Ula Nganjuk, Yayasan Pondok Pesantren Al-Ghozali Nganjuk, dan Yayasa Pondok Pesantren Darut Taqwa Sengonagung Pasuruanuntuk mencari alternatif pembelajaran yang efektif di masa pandemi Covid-19 ini.

\section{Persiapan Pendampingan}

Pada tahap pertama, tim melakukan persiapan pendampingan bagi para pendidik. Tim telah dibagi tugas dan peran masing-masing untuk melakukan studi awal problem yang dihadapi pada lembaga pendidikan di masa pandemi Covid-19 ini serta melakukan diskusi dengan pemangku kebijakan di masing-masing Yayasan. Tim dosen STAI Miftahul Ula Nganjuk melakukan studi awal pada lembaga pendidikan di bawah naungan Yayasan Miftahul Ula Nganjuk, Tim Dosen STAI Darussalam Krempyang Nganjuk melakukan studi awal di Yayasan Al-Ghozali Nganjuk, Tim Dosen IAI Sunan Kalijogo Malang melakukan studi awal di Yayasan Sunan Kalijogo Malang, dan Tim Universitas Yudharta melakukan studi awal di Yayasan Darut Taqwa Sengonagung Purwosari Pasuruan.

Hasil studi awal didapatkan bahwa persoalan yang dihadapi oleh tenaga pendidik adalah mengalami "fase kebingungan" masa transisi model pembelajaran yang 
efektif, antara masa normal menuju masa pandemi Covid-19. Karena pendidikan yang dikembangkan di keempat Yayasan tersebut mempunyai karakteristik yang sama, yakni lembaga berbasis pesantren yang relatif membatasi penggunaan media online dalam proses belajar mengajar. Kalaupun ada penggunaan media online, namun media tersebut masih belum digunakan sebagai media utama dalam proses belajar mengajar dengan siswa. Mereka masih banyak bertumpu dengan pendekatan klasikal dengan langsung tatap muka di kelas antara guru dengan siswa. Dari hasil studi awal tersebut, maka tim melakukan diskusi dengan pemangku kebijakan di Yayasan untuk melakukan pendampingan bagi para tenaga pendidik dalam redesign pembelajaran berbasis online di masa pandemi Covid-19 ini.

\section{Layanan Pendampingan}

Tahap selanjutnya adalah melakukan layanan pendampingan bagi tenaga pendidik di bawah naungan Yayasan Sunan Kalijogo Malang, Yayasan Miftahul Ula Nganjuk, Yayasan Al-Ghozali Nganjuk, dan Yayasa Darut Taqwa Sengonagung Pasuruan. Peserta yang terlibat dalam pendampingan ini adalah para pendidik pada lembaga pendidikan tingkat dasar sampai pendidikan tinggi di bawah naungan Yayasan tersebut.

Proses pendampingan ini dilakukan dengan memanfaatkan media social WhatsAPP Group, sehingga layanan pendampingan bisa dilakukan lintas sektoral dan wilayah. Selain itu, pendampingan juga dilakukan secara intensif dengan peer group di masing-masing lembaga pendidikan sesuai kebutuhan oleh para Tim Pendamping dengan membagi sesuai wilayah masing-masing, yakni Tim dosen STAI Miftahul Ula Nganjuk melakukan pendampingan pendidik di Yayasan Miftahul Ula Nganjuk, Tim Dosen STAI Darussalam Krempyang Nganjuk di Yayasan Al-Ghozali Nganjuk, Tim Dosen IAI Sunan Kalijogo Malang di Yayasan Sunan Kalijogo Malang, dan Tim Universitas Yudharta di Yayasan Darut Taqwa Sengonagung Purwosari Pasuruan pada multi jenjang sesuai kebutuhan di masing-masing lembaga.

Melalui virtual learning WhatsAPP Group tersebut, para pendidik dikenalkan berbagai media online yang bisa dimanfaatkan dalam membuat proses belajar mengajar pembelajaran online secara efektif. Mulai dari bagaimana pemanfaatan media social (WhatsAPP, Facebook), Learning Management System (Edmodo, Google Classroom, Moodle), Video Conference (Zoom, Google Meet). Para pendidik bisa memilih berbagai media tersebut untuk digunakan dalam proses belajar mengajar di kelas dan disesuaikan dengan kebutuhan mereka di lembaga mereka masing-masing.

Untuk mempermudah penyampaian materi virtual learning ini, Tim juga telah membuat video tutorial step by step pembelajaran online, salah satunya tutorial penggunaan Learning Management System (LMS) Edmodo. Para pendidik dipandu secara bertahap oleh tim untuk memahami LMS Edmodo, serta mereka langsung praktek melalui laptop atau handphone mereka masing-masing, mulai dari materi instalasi program LMS Edmodo, setting kelas dalam Edmodo, membuat tugas dalam 
Edmodo, penilaian Edmodo, serta bagaimana kiat-kiat agar pemanfaatan LMS ini bisa maksimal. Hal inilah yang membedakan dengan tutorial pada umumnya, karena setiap tahapan telah diberikan materi sekaligus contohnya melalui video tutorial step by step, baik untuk guru maupun untuk siswa, sebagaimana terlihat pada Gambar 1.

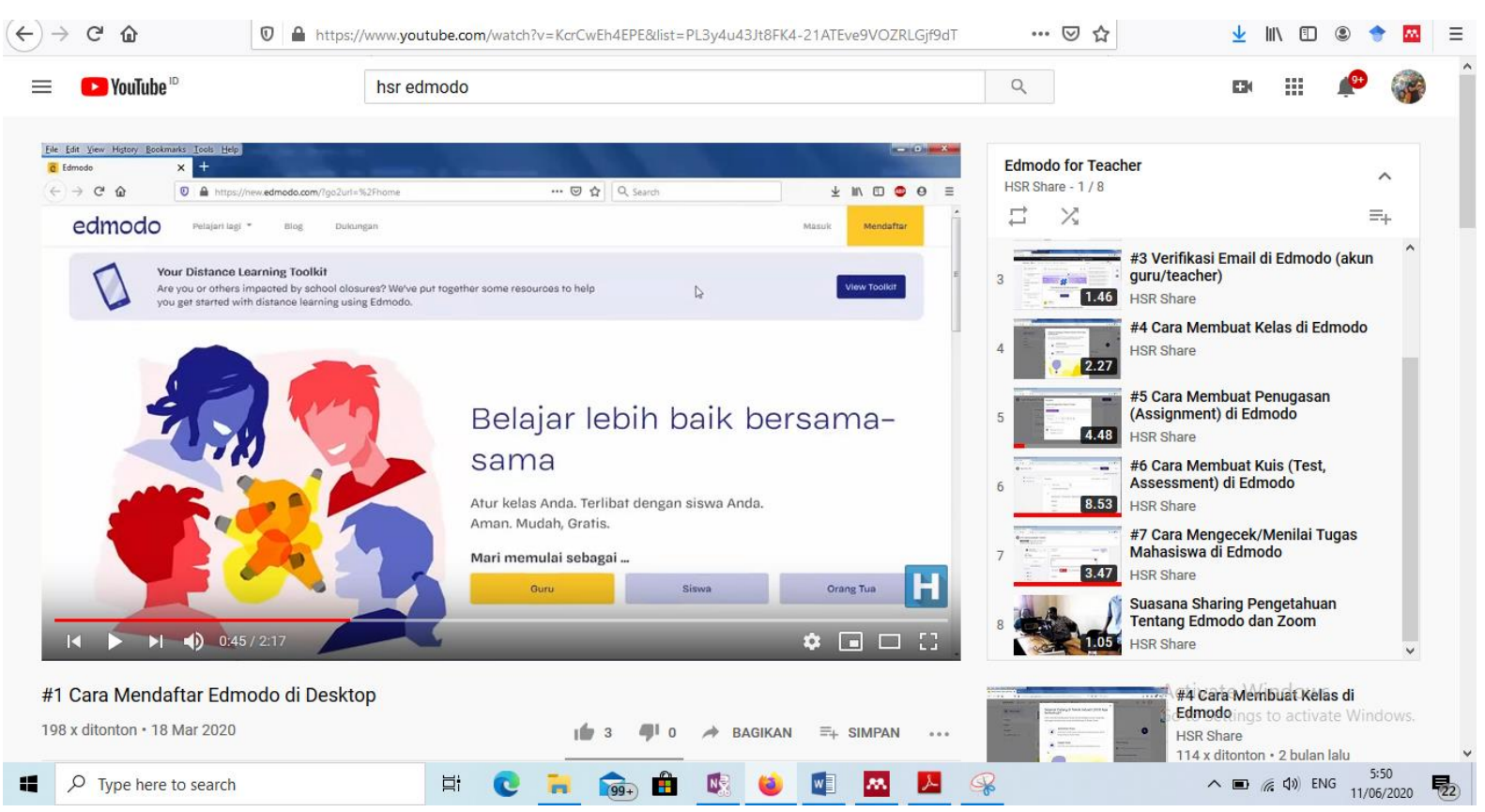

Gambar 1. Tampilan Salah satu Tutorial Learning Management System Edmodo ${ }^{10}$

Selain itu, para pendidik juga dikenalkan video conference Zoom, mulai dari pengenalan dan apa manfaat video conference, cara instalasi, cara membuat kelas online serta bagaimana mengoperasionalkannya. Untuk memberikan pemahaman yang lebih jelas, mereka juga diajak praktek langsung bagaimana penggunaan Zoom dan bersamasama melakukan video conference antar para pendidik.

Untuk mengawal tindak lanjut virtual learning bagi para pendidik ini, tim juga melakukan pendampingan secara offline di masing-masing Yayasan sesuai dengan pembagian tugas yang telah disepakati bersama. Tim memberikan gambaran bahwa apa yang sudah diberikan dalam virtual learning adalah contoh media online yang bisa dimanfaatkan oleh para pendidik. Untuk pilihan mana yang terbaik, para pendidik bisa menyesuaikan atau menggunakan sesuai dengan kebutuhan dan kenyamanan antara pendidik dan para siswa.

Setelah melalui tahapan layanan, tahapan berikutnya adalah refleksi hasil pendampingan. Dalam refleksi ini dapat dilihat dari feedback yang diberikan oleh pendidik pada saat mengikuti virtual learning melalui WhatssAPP Group, maupun

10 Video Tutorial tersebut dibuat oleh Anggota Tim Hasan Syaiful Rizal (Universitas Yudharta Pasuruan). Video tutorial tersebut dibuat Step by Step mulai dari Pendaftaran sampai Pemberian Penilaian Tugas dan dishare melalui channel Youtube hsr share di link https://www.youtube.com/watch?v=KcrCwEh4EPE\&list=PL3y4u43Jt8FK4-21ATEve9VOZRLGjf9dT. 
keputusan dalam penggunaan media online di masing-masing lembaga pendidikan masing-masing.

Hasil refleksi dari proses virtual learning bagi pendidik memberikan respon yang sangat baik dan dirasakan memberikan manfaat yang cukup besar bagi mereka, sebagaimana tersaji dalam grafik pada Gambar 2.

Menurut anda, apakah grup virtual learning ini bermanfaat untuk anda dalam pengembangan

e-learning?

200 tanggapan

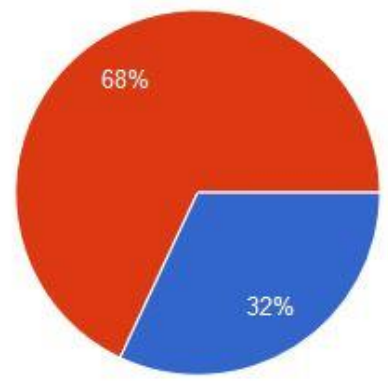

Gambar 2. Tingkat Kemanfaatan Proses Virtual Learning bagi Pendidik

Berdasarkan data pada Gambar 2, menunjukkan bahwa para pendidik sebanyak $32 \%$ memberikan feedback bermanfaat, dan 68\% menyatakan sangat bermanfaat, dan tidak ada yang menjawab (0\%) kurang bermanfaat atau tidak tahu.

Terkait dengan tindak lanjut pasca keiatan virtual learning melalui media WhatssAPP Group, para pendidik menyatakan 45\% sudah memanfaatkan Edmodo, 51,5\% baru belajar Edmodo, dan akan memanfaatkan dalam belajar mengajar, sisanya menjawab tidak tahu dan masih dipelajari dahulu $(3,5 \%)$, sebagaimana dapat dilihat pada Gambar 3.

Apakah anda akan memanfaatkan Edmodo dan Zoom sebagai Salah satu Media

Pembelajaran anda?

200 tanggapan

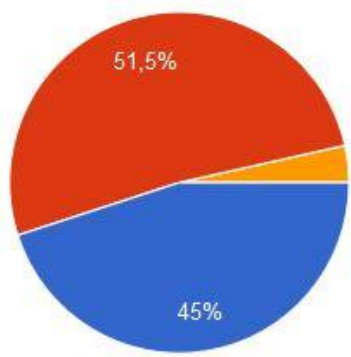

Ya, sudah saya manfaatkan

Ya, Saya baru membuat akun Edmodo,

dan akan saya manfaatkan

Tidak tahu, masih saya pelajari dahulu

Gambar 3. Data Respon Pendidik Untuk Tindak Lanjut Pasca Virtual Learning

Refleksi setelah proses pendampingan tenaga pendidik melalui virtual learning, di level lembaga pendidikan masing-masing, para pendidik telah memiliki gambaran yang baik untuk penggunaan berbagai media online. Hasil pantauan dari Tim 
Pendamping, sebagian besar mereka memanfaatkan media sosial seperti WhatsApp sebagai media utama dalam penyampaian dan komunikasi materi dengan para siswa mereka. Untuk Learning Management System (LMS) masih digunakan sebagai media pendukung dalam mengumpulkan tugas, karena sangat mudah bagi mereka untuk memilah dan memberikan penilaian tugas dari siswa. LMS yang dipilih bahyak yang menggunakan Google Classroom, dan sebagian memanfaatkan Edmodo. Pilihan ini dilakukan Untuk Video Conferece (Zoom, Google Classroom) masing belum dimanfaatkan secara maksimal dan hanya sebagai media pendukung saja, karena para siswa sebagian besar merasa berat terkait dengan kuota data online yang cukup besar. Para pendidik juga menyadari dan menyesuaikan dengan kondisi dan kemampuan dari masingmasing siswa yang dihadapi oleh mereka.

Pembelajaran jarak jauh adalah salah satu mode pembelajaran online yang tidak memerlukan tatap muka. Ini pada dasarnya adalah sebuah alternatif pengajaran dan pembelajaran yang diberikan oleh sebuah mode, di mana ada pemisahan fisik antara guru dan pelajar atau di antara peserta didik sendiri. ${ }^{11}$ Dengan mode ini pembelajaran online, ada pencegahan dan kontrol atas penyebaran virus. ${ }^{12}$

Dari hasil kajian, beberapa system pembalajaran yang bisa dipakai secara online adalah sebagai berikut:

\section{Social Media (WhatsApp dan Facebook)}

Penggunaan media sosial, terutama Facebook dan WhatsApp ke dalam proses belajar-mengajar telah meningkat secara signifikan dalam beberapa waktu terakhir. Media sosial telah menjadi gerbang dinamis untuk memberikan informasi pendidikan di seluruh dunia sejak deteksi pandemi Covid-19 pada bulan Desember, 2019.13 Platform ini menyediakan berbagai pengalaman belajar dan lingkungan pengajaran yang baru dan menarik bagi para pendidik, yang tidak mungkin didapat dalam pendidikan tradisional. ${ }^{14}$ Dengan demikian, penggunaan Facebook dan WhatsApp akan menawarkan kesempatan yang lebih baik untuk pendidikan online,

11 Emmanuel Chisa Ibara, "Open and Distance Learning: An Emerging System for Alternative Higher Education in Nigeria," Turkish Online Journal of Distance Education 9, no. 1 (2008): 118-122; Morayo Jimoh, An Appraisal of the Open and Distance Learning Programme in Nigeria (LAP LAMBERT Academic Publishing, 2014); Rashid Aderinoye and Kester Ojokheta, "Open-Distance Education as a Mechanism for Sustainable Development: Reflections on the Nigerian Experience," The International Review of Research in Open and Distributed Learning 5, no. 1 (2004); Onyemaechi Joseph Onwe, "Policies and Practice of Open and Distance Learning Models in the Sub-Saharan African Countries: A Literature Survey," Journal of Teacher Perspective 8, no. 2 (2014).

12 Toquero, "Challenges and Opportunities for Higher Education amid the COVID-19 Pandemic: The Philippine Context."

13 Eddie Mumba Mulenga and José María Marbàn, "Social Media Usage among Pre-Service Secondary Mathematics Teachers in Zambia," JRAMathEdu (Journal of Research and Advances in Mathematics Education) 5, no. 2 (2020): 130-147; Eddie M Mulenga and José M Marbán, "Is COVID-19 the Gateway for Digital Learning in Mathematics Education?," Contemporary Educational Technology 12, no. 2 (2020): ep269.

${ }^{14}$ D Praveen Sam, "Learning beyond the Classroom through WhatsApp: An Informal Channel to Motivate Learners to Stay Connected," Asian Journal of Research in Social Sciences and Humanities 6, no. 9 (2016): 1826-1833. 
terutama selama pandemi Covid-19. Sangat penting bagi sekolah untuk menggunakan teknik pengajaran yang inovatif dan pendekatan seperti media sosial selama krisis Covid-19 ini dan seterusnya. 15

pendidik mengadakan sesi kelas di media sosial, saat menggunakan Facebook dan WhatsApp untuk menciptakan sumber daya bagi siswa dan melakukan diskusi pendidikan Penggunaan Facebook dan WhatsApp akan menawarkan akses ke sumber belajar kapan saja dan di mana saja dan dalam berbagai bentuk seperti audio, video dan cetak, yang berpotensi akan meningkatkan pembelajaran yang mendalam dan memungkinkan siswa untuk membangun pengetahuan sendiri dan mengembangkannya.

\section{Virtual Classroom}

Virtual Classroom adalah pilihan lain untuk proses pengajaran dan pembelajaran di kelas secara tatap muka, yang dapat diadopsi oleh pendidik ${ }^{16}$. Kelas virtual menawarkan materi kursus kepada peserta didik, Selain itu, menyediakan lingkungan hidup, kontekstual dan interaktif. Kelas virtual pada dasarnya adalah pengaturan kelas online di mana peserta didik bersama dengan guru mereka secara aktif terlibat dalam pertemuan instruksional sinkron. Seperti di dalam kelas tatap muka pengajaran dan belajar perusahaan, kelas virtual akan sama-sama membutuhkan baik instruktur dan siswa untuk masuk ke dalam kelas pada waktu yang sama ${ }^{17}$.

Pelaksanaan kelas virtual akan menjadi inisiatif yang akan memberikan kesempatan belajar online yang fleksibel bagi jutaan siswa untuk terus belajar dari rumah. Ini akan memberi siswa kesempatan untuk mengakses pelajaran/ceramah virtual yang akan membantu proses pembelajaran.

3. Mobile Learning

Pengenalan perangkat genggam digital dan komputer pribadi serta penerimaan konsensual pedagogi baru di abad ke-21 telah mempercepat revolusi teknologi yang melihat lebih banyak siswa dan guru meningkatkan penggunaan perangkat elektronik di sekolah. M-Learning secara luas dianggap sebagai proses pengajaran dan pembelajaran yang dibantu dengan penggunaan perangkat mobile dan platform terkait lainnya ${ }^{18}$. Bentuk pembelajaran bersimpangan komputasi mobile dan $e$ Learning dan mengadopsi penggunaan teknologi mobile seperti smartphone, Personal digital Assistant (PDA), tablet PC dan laptop PC untuk mencapai kapan saja,

15 Toquero, "Challenges and Opportunities for Higher Education amid the COVID-19 Pandemic: The Philippine Context."

16 Zheng Yan, "Unprecedented Pandemic, Unprecedented Shift, and Unprecedented Opportunity," Human Behavior and Emerging Technologies 2, no. 2 (2020): 110-112.

${ }_{17}$ R H Huang et al., "Handbook on Facilitating Flexible Learning during Educational Disruption: The Chinese Experience in Maintaining Undisrupted Learning in COVID-19 Outbreak," Beijing: Smart Learning Institute of Beijing Normal University (2020).

18 Luís Francisco Mendes Gabriel Pedro, Cláudia Marina Mónica de Oliveira Barbosa, and Carlos Manuel das Neves Santos, "A Critical Review of Mobile Learning Integration in Formal Educational Contexts," International Journal of Educational Technology in Higher Education 15, no. 1 (2018): 10. 
di mana saja, di mana-mana belajar, yang menekankan peserta didik mobilitas dan personalisasi belajar ${ }^{19}$.

MB-Learning memang merupakan paradigma pembelajaran yang menawarkan beberapa jalan belajar alternatif yang menjanjikan, yang mampu memberikan kesempatan belajar yang menarik bagi siswa selama pandemic ini berlangsung 20 . Hal ini karena terjalin dengan kegiatan sehari-hari dan berlangsung Kapan saja dan di setiap lokasi, tidak perlu dalam ruang kelas. Hal ini memungkinkan siswa untuk belajar, berkolaborasi, dan berbagi ide di antara mereka sendiri 21 . Oleh karena itu, M-Learning adalah teknologi pendidikan penting yang harus diimplementasikan di sekolah untuk memberikan pendidikan berkelanjutan kepada siswa, terutama selama krisis pendidikan Covid-19 ini.

Namun, berdasarkan proses pendampingan yang sudah dilakukan selama pandemi Covid-19 menunjukkan bahwa media sosial WhatssApp dan mobile learning dengan menggunakan handphone masih menjadi "primadona" bagi para pendidik dalam melaksanakan proses belajar mengajar di masa pandemi Covid-19 ini.

\section{Kesimpulan}

Program pengabdian kepada masyarakat melalui pendampingan redesign pembelajaran pada masa pandemi Covid-19 merupakan salah satu solusi dari kondisi pandemi yang memaksa para pendidik dari model klasikal ke pembelajaran online untuk meminimalisir penyebaran Covid-19 pada peserta didik. Melalui online service learning, pendampingan ini dilakukan kepada para pendidik dalam masa transisi model pembelajaran dari klasikal ke pembelajaran online. Melalui pendampingan ini, para pendidik semakin memiliki kemampuan untuk menggunakan berbagai media online dalam pembelajaram, baik yang berbasis media sosial, learning management system, maupun video conference. Dampak dari pendampingan ini adalah setiap pendidik telah memiliki kemampuan untuk memilih media online yang terbaik bagi mereka yang sesuai dengan kebutuhan dan kemampuan peserta didik. Sebagian besar, para pendidik memanfaatkan media sosial WhatsApp sebagai media komunikasi dan pengajaran di kelas, dan manejemen penugasan sebagian memanfaatkan learning management system google classroom dan Edmodo. Sedangkan video comference hanya digunakan oleh para pendidik sebagai media pendukung saja, bukan sebagai media utama dalam proses pembelajaran.

19 Ken Nee Chee et al., "Review of Mobile Learning Trends 2010-2015: A Meta-Analysis," Journal of Educational Technology \& Society 20, no. 2 (2017): 113-126.

20 Aziz Naciri et al., "Mobile Learning in Higher Education: Unavoidable Alternative during COVID-19," Aquademia 4, no. 1 (2020): ep20016.

21 Ibid. 


\section{Daftar Referensi}

Aderinoye, Rashid, and Kester Ojokheta. "Open-Distance Education as a Mechanism for Sustainable Development: Reflections on the Nigerian Experience." The International Review of Research in Open and Distributed Learning 5, no. 1 (2004).

Chee, Ken Nee, Noraffandy Yahaya, Nor Hasniza Ibrahim, and Mohamed Noor Hasan. "Review of Mobile Learning Trends 2010-2015: A Meta-Analysis." Journal of Educational Technology \& Society 20, no. 2 (2017): 113-126.

CHUKWUEMEKA, E J, C C NSOFOR, O C FALODE, and A ANIAH. "ASSESSING PRESERVICE TEACHERS'TECHNOLOGICAL PEDAGOGICAL CONTENT KNOWLEDGE SELF-EFFICACY TOWARDS TECHNOLOGY INTEGRATION IN COLLEGES OF EDUCATION IN SOUTH-WEST NIGERIA" (n.d.).

Hikmawati, Sholihatul Atik. "Penerapan Mode Kooperatif Model Teams-GamesTournaments (TGT) Untuk Meningkatkan Motivasi Dan Hasil Belajar Maharah Qira'ah Siswa Kelas XII Bahasa MAN Batu." Penerapan Mode Kooperatif Model Teams-Games-Tournaments (TGT) Untuk Meningkatkan Motivasi Dan Hasil Belajar Maharah Qira'ah Siswa Kelas XII Bahasa MAN Batu/Sholihatul Atik Hikmawati. Universitas Negeri Malang. Program Studi Pendidikan Bahasa Arab, 2010.

Huang, R H, D J Liu, A Tlili, J F Yang, and H H Wang. "Handbook on Facilitating Flexible Learning during Educational Disruption: The Chinese Experience in Maintaining Undisrupted Learning in COVID-19 Outbreak." Beijing: Smart Learning Institute of Beijing Normal University (2020).

Ibara, Emmanuel Chisa. "Open and Distance Learning: An Emerging System for Alternative Higher Education in Nigeria." Turkish Online Journal of Distance Education 9, no. 1 (2008): 118-122.

Jimoh, Morayo. An Appraisal of the Open and Distance Learning Programme in Nigeria. LAP LAMBERT Academic Publishing, 2014.

Liu, Peilin, Lei Shi, Wei Zhang, Jianan He, Chunxiao Liu, Chunzhong Zhao, Siu Kai Kong, Jacky Fong Chuen Loo, Dayong Gu, and Longfei Hu. "Prevalence and Genetic Diversity Analysis of Human Coronaviruses among Cross-Border Children." Virology Journal 14, no. 1 (November 22, 2017): 230.

Mulenga, Eddie M, and José M Marbán. “Is COVID-19 the Gateway for Digital Learning in Mathematics Education?" Contemporary Educational Technology 12, no. 2 (2020): ep269.

Mulenga, Eddie Mumba, and José María Marbàn. "Social Media Usage among Pre-Service Secondary Mathematics Teachers in Zambia." JRAMathEdu (Journal of Research and Advances in Mathematics Education) 5, no. 2 (2020): 130-147.

Naciri, Aziz, Mohamed Amine Baba, Abderrahmane Achbani, and Ahmed Kharbach. "Mobile Learning in Higher Education: Unavoidable Alternative during COVID-19." Aquademia 4, no. 1 (2020): ep20016.

Nasruddin, Rindam, and Islamul Haq. "Pembatasan Sosial Berskala Besar (PSBB) Dan Masyarakat Berpenghasilan Rendah.” SALAM: Jurnal Sosial dan Budaya Syar-i 7, no. 7 (2020). 
Nusanti, Irene. "Strategi Service Learning Sebuah Kajian Untuk Mengembangkan Kegiatan Pembelajaran." Jurnal Pendidikan dan Kebudayaan 20, no. 2 (2014): 251260.

Olim, Ayi. "Mencari Metode Pendidikan Karakter Untuk Paud : Belajar Berbasis Layanan ( Service Learning )." In Proceedings of The 4th International Conference on Teacher Education; Join Conference UPI \& UPSI, 146-161. Bandung: UPI \& UPSI Bandung, 2010.

Onwe, Onyemaechi Joseph. "Policies and Practice of Open and Distance Learning Models in the Sub-Saharan African Countries: A Literature Survey." Journal of Teacher Perspective 8, no. 2 (2014).

Pedro, Luís Francisco Mendes Gabriel, Cláudia Marina Mónica de Oliveira Barbosa, and Carlos Manuel das Neves Santos. "A Critical Review of Mobile Learning Integration in Formal Educational Contexts." International Journal of Educational Technology in Higher Education 15, no. 1 (2018): 10.

Sam, D Praveen. "Learning beyond the Classroom through WhatsApp: An Informal Channel to Motivate Learners to Stay Connected." Asian Journal of Research in Social Sciences and Humanities 6, no. 9 (2016): 1826-1833.

Shira, Dezan. “China Extends Lunar New Year Holiday to Feb 2, Shanghai to Feb 9." Last modified 2020. Accessed April 5, 2020. https://www.chinabriefing.com/news/china-extends-lunar-new-year-holiday-february-2-shanghaifebruary-9-contain-coronavirus-outbreak/.

Toquero, C M. "Challenges and Opportunities for Higher Education amid the COVID-19 Pandemic: The Philippine Context." Pedagogical Research 5, no. 4 (2020).

Wajdi, Muh Barid Nizarudin, Iwan Kuswandi, Umar Al Faruq, Zulhijra Zulhijra, Khairudin Khairudin, and Khoiriyah Khoiriyah. "Education Policy Overcome Coronavirus, A Study of Indonesians." EDUTEC: Journal of Education And Technology 3, no. 2 (2020): 96-106.

Waldner, Leora S, Murray C Widener, and Sue Y McGorry. "E-Service Learning: The Evolution of Service-Learning to Engage a Growing Online Student Population." Journal of Higher Education Outreach and Engagement (2012): 123-150.

WHO. "Coronavirus." Last modified 2020. Accessed April 5, 2020. https://www.who.int/health-topics/coronavirus\#tab=tab_1.

Yan, Zheng. "Unprecedented Pandemic, Unprecedented Shift, and Unprecedented Opportunity." Human Behavior and Emerging Technologies 2, no. 2 (2020): 110112.

"Kementerian Pendidikan Dan Kebudayaan » Republik Indonesia." Accessed June 10, 2020. https://www.kemdikbud.go.id/main/blog/2020/03/sikapi-covid19kemendikbud-terbitkan-dua-surat-edaran. 